\title{
GAYA RESOLUSI KONFLIK PESANTREN DI BALI
}

\author{
Haya \\ Universitas Bhakti Indonesia Banyuwangi \\ hayaudin1974@gmail.com \\ Jamaludin Nibun \\ STAI Asy-Syukriyyah \\ jamaludin@asy-syukriyyah.ac.id
}

\begin{abstract}
Riset ini membahas pesantren yang ada di Bali dengan fokus studi pada gaya resolusi konflik dalam perspektif Islam, yaitu tugas pokok dan fungsinya sebagai rahmat bagi seluruh umat manusia. Islam adalah agama damai yang memberikan perlindungan dan rasa aman kepada masyarakat untuk melakukan sesuatu sesuai dengan keyakinannya masingmasing. Pandangan tersebut mendasari adanya pasal 29 UUD 1945 yang mengharuskan adanya sikap saling menghormati dan menghargai antar sesama manusia tanpa memandang adanya latar belakang SARA.Metode dalam penelitian ini merupakan metode kualitatif dengan dengan field riset yang dimana mengambil dua pesantren yang ada di provinsi bali yakni Pesantren Istiqlal Buleleng dan Bali Bina Insani. Adapun Hasil Penelitiannya adalah Pertama, varian konflik di Bali adalah horizontal dengan melibatkan komunitas Muslim dan Non Muslim yang terjadi akibat adanya disharmoni dan kesalahpahaman. Kedua, kiai menerapkan pola penyelesaiakan konflik yang bertumpu pada gaya kompromi karena memiliki pemahaman dan keyakinan yang tinggi terhadap kebenaran ajaran agama Islam
\end{abstract}

Keywords: Gaya, Resolusi, Konflik, Pesantren

\section{PENDAHULUAN}

Secara global resolusi konflik pesantren memiliki makna tersendiri dimana dunia internasional, hingga saat ini, masih mengalami konflik horizontal yang demikian hebat. Beberapa negara Islam seperti Irak, Iran, Syiria, Libanon, Turki sedang dilanda masalah keamanan akibat adanya kontak senjata dengan para pemberontak atau penggangggu keamanan negara. Selain itu, Korea Utara dan Korea Selatan juga dilanda konflik berkepanjangan yang berakibat pada kekhawatiran negara di sekitarnya. Di sisi lain, bangsa-bangsa di dunia mengalami ancaman terorisme yang melakukan tindak kekerasan atas nama agama. 
Indonesia berupaya keras membendung konflik horizontal di beberapa Propinsi maupun Kabupaten dengan menggelorakan trilogi kerukunan, yaitu kerukunan antar umat beragama, kerukunan antar umat seagama dan kerukunan antar umat beragama dengan pemerintah. ${ }^{1}$ Tahun 2016, pemerintah menerbitkan peraturan tentang ujaran kebencian sebagai upaya preventif atas terjadinya konflik di masyarakat akar rumput. Gerakan massa Islam di Jakarta yang melakukan demo kepada Gubernur Basuki Cahaya Purnama (Ahok) atas tuduhan pelecehan ayat suci al-Qur'an. Fenomena ditengarai bernuansa SARA dan mendapat tanggapan luas dari umat Muslim di Indonesia. ${ }^{2}$ Jika dibiarkan, kondisi tersebut dapat mengakibatkan terjadinya konflik yang semakin meluas.

Menyikapi kondisi keamanan dunia akhir-akhir ini, Presiden Joko Widodo berharap bangsa-bangsa di dunia menjaga stabilitas politik dan keamanan untuk mencapai pertumbuhan ekonomi dengan membina kehidupan yang harmoni antar sesama. Dalam suatu acara resmi kenegaraan, Jokowi Mengatakan dengan tegas:

"Konflik dan perang tidak akan menguntungkan siapapun. Masyarakat terutama anakanak dan wanita menjadi pihak yang paling dirugikan dengan adanya konflik dan perang". 3

Konflik dan perang menghancurkan nilai-nilai luhur yang diberikan Allah SWT.

Secara nasional, Indonesia dikenal memiliki pengalaman yang baik dalam mengelola keragaman hidup dalam beragama, suku, adat dan ras dengan pendekatan yang damai. Namun demikian, Indonesia juga mengalami persoalan keamanan seperti konflik Poso, Aceh maupun Papua. Para pihak berkepentingan berupaya menarik konflik horizontal tersebut menjadi

\footnotetext{
${ }^{1}$ M. Quraish Shihab, “Membumikan” al-Qur'an: Fungsi dan Peranan Wahyu dalam Kehidupan (Bandung: Mizan, 2007), 561-562.

${ }^{2}$ www.bbc.com Indonesia, Aksi 212: Rizieq Shihab dan Menyeru Penjarakan Ahok.

3 https://www.antaranews.com/berita/680922/presiden-jangan-biarkan-dunia-dalam-situasi-konflik.
} 
konflik bernuansa sara (suku, agama, ras dan adat). Konflik atas nama agama juga terjadi di Pulau Dewata Bali.

Bali adalah wajah keindahan Indonesia yang telah dikenal dunia semenjak lama. Di Bali terdapat Pantai Kuta, Pantai Pandawa, Pantai Sanur, Nusa Dua dll, sehingga dikenal sebagai Pulau Dewata. Pesona Bali mampu manarik para Turis domestik maupun mancanegara untuk mengunjunginya. Mereka menjadikan Bali sebagai destinasi wisata. Di satu sisi, kedatangan para turis merupakan potensi ekonomi. Namun, disisi lain, sekelompok orang memahaminya sebagai petaka kebudayaan karena dianggap membawa kultur yang bertentangan dengan ajaran agamanya. Pandangan tersebut mengakibatkan terjadi kesalah-pahaman sehingga memicu terjadinya tindakan yang anarkhis dengan alasan agama.

Pada tahun 2002, Bali dikejutkan dengan adanya Bom 1 yang mengguncang Legian (Paddy's Pub dan Sari Club) dan lokasi di dekat Konsulat Amerika di Bali. Kejadian tersebut menelan korban 202 meninggal dan 209 lainnya mengalami luka dan cedera. ${ }^{4}$ Pada tahun 2005 terjadi Bom Bali II. Peristiwa-peristiwa tersebut ditengarai sebagai kejahatan terorisme yang mengancam sendi-sendi kehidupan berbangsa dan bernegara.

Di sisi lain, Pesantren di Bali memiliki cara yang unik dalam mengelola konflik. Warga pesantren di sana bisa hidup berdampingan dengan Non Muslim dalam situasi yang saling menghormati. Mereka melakukan aktifitas sehari-hari maupun kebudayaannya dengan penuh rasa hormat. Para kiai di Bali menambahkan identitas Bali sebelum nama Islam-nya, seperti Wayan Syamsul Bahri, I Gede Hayaudin maupun Putu Zainudin.

Di Pesantren Bali Bina Insani Tabanan, suasana kehidupannya menyembulkan adanya saling memahami antara pemeluk Islam dan Hindu. Mereka hidup secara berdampingan dan memiliki sikap saling tolong menolong. Beberapa warga Hindu hidup berdampingan dan

\footnotetext{
${ }^{4}$ https://id.wikipedia.org/wiki/Bom_Bali_2002
} 
bekerja di Pesantren tersebut secara profesional. Mereka bekerja sebagai guru dan tenaga satpam pesantren melayani keperluan hidup santri dan belajar bersama.

Selain realitas sosial budaya di atas, Stephen P. Robbins meneliti tentang Conflict Management yang mengulas fenomena konflik dalam organisasi. Dengan mengutip konsep sosiologi, dikatakannya bahwa konflik merupakan penanda suatu masyarakat atau organisasi. Adanya konflik di suatu masyarakat menjadi bukti kehidupan suatu organisasi. namun demikian masyarakat tidak menginginkan suatu konflik terjadi. Konflik dapat dikelola menjadi suatu kekuatan organisasional untuk mencapai tujuan organisasi.

Ghorbani dan Razavi dalam the study of reletionship between organizational culture and conflict management ${ }^{5}$ menelti relevansi antara gaya manajemen konflik dan kultur lembaga pendidikan tinggi di Iran. Hasil analisisnya menyatakan adanya hubungan antara gaya manajemen konflik dengan kultur budaya rasional yang dikembangkan beberapa universitas di negeri para Mullah tersebut. Penelitian Ghorbani dan Razavi berkonstribusi pada gaya manajemen konflik para manajer dalam mengembangkan budaya organisasi dengan pendekatan konflik.

Basori dalam manajemen konflik di tengah dinamika pondok pesantren dan madrasah ${ }^{6}$ menyatakan bahwa konflik juga menimpa dunia pendidikan Islam khususnya pesantren dan madrasah. Basori menyimpulkan bahwa manajemen konflik memiliki peran yang signifikan dalam resolusi konflik di pesantren dan madrasah. Dengan demikian, resolusi konflik menjadi strategi dalam pengembangan dunia pendidikan pesantren dimana konflik merupakan sitausi yang tidak bisa dielakkan dalam kancah global, regional maupun lokal.

${ }^{5}$ Mahmood Ghorbani And Nazanin Homaye Razavi, the study of reletionship between organizational culture and conflict management,(Middle East Journal Of Scientific Research 10 (2), 2011), 711-717.

${ }^{6}$ Bashori, Manajemen konflik di tengah dinamika pondok pesantren dan madrasah Muslim Heritage, Vol.1 nomor 2 November 2016-April 2017. 
Penelitian Atif Masood Chaudhry dan Rehman Asif berjudul Organizational Conflict and Conflict Management; A Synthesis Of Literature. ${ }^{7}$ Temuannya telah memperkaya khazanah keilmuan manajemen khususnya tentang komponen konflik menyangkut emosional, saling menerima dan kemampuan menyelesaikan gesekan merupakan faktor eternal yang dapat menjadikan konflik menjadi potensi organisasi. Komponen-komponen tersebut menjadi faktor pemicu dimana konflik dapat meningkatkan performa organisasi. Kesimpulan tersebut mengkoreksi pandangan klasik bahwa konflik merupakan energi negatif yang merugikan lembaga.

Berbagai literatur di atas telah membicarakan fenomena konflik di perusahaan dengan varian konflik antar personal atas berbagai kepentingan yang melatar-belakangi. Resolusi konflik diarahkan kepada bagaimana menyelesaikan konflik secara efektif dan efisien untuk mencapai tujuan perusahaan. Selain itu, fenomena tentang pesantren telah banyak disorot melalui kajian maupun pendekatan keilmuan tertentu, termasuk manajemen pendidikan Isla. Akan tetapi, terdapat satu masalah khusus yang belum dikaji secara serius, yaitu gaya resolusi konflik pesantren.

\section{KAJIAN TEORI}

Pembahasan mengenai konflik pesantren merupakan topik yang terlantar dalam manajemen pendidikan Islam. Dalam banyak literatur dapat dijumpai pembahasan mengenai konflik yang bersifat interpersonal dengan setting perusahaan. Penelitian mengenai manajemen konflik telah dilakukan oleh Aubert (1963), Assael (1969), Kelly (1970), Dautsch (1969), Kilmann (1977), Ghorbani Razafi (2011), maupun Bashori (2017).

${ }^{7}$ Atif Masood Chaudhry And Rehman Asif, Organizational Conflict and Conflict Management; A Synthesis Of Literature, (Journal of Business and Management Research, 9, 2015), 238-244. 
Penelitian ini memakai teori gaya manajemen konflik Thomas- Kilman yang memandang konflik sebagai keniscayaan bagi suatu organisasi. ${ }^{8}$ Konflik merupakan bagian tidak terpisahkan dari organisasi, bahkan dipandang sebagai penanda keberadaan atau ketiadaannya. ${ }^{9}$ Dengan demikian, konflik tidak bisa dihindari, namun dikelola secara efektif. ${ }^{10}$ Hakikatnya, manajemen konflik adalah pengelolaan dampak-dampak konflik terhadap efektifitas organisasi. Dalam hal ini, Ralph K. Hilmann dan Kenneth W. Thomas mengemukakan gaya manajemen konflik meliputi meliputi dua unsur yaitu gaya keasertifan vertikal dan gaya kerjasama horizontal konflik. $^{11}$ Keasertifan mencakup perhatian terhadap diri atau kelompoknya dalam berkonflik, sementara kerjasama memerhatikan kepentingan pihak lawan. Gaya manajemen konflik memiliki lima aspek, yaitu kompetisi, kolaborasi, kompromi, menghindari, dan akomodatif. ${ }^{12}$

\section{Gambar 1}

\section{Gaya Manajemen Konflik ${ }^{13}$}

\section{Asertiveness}

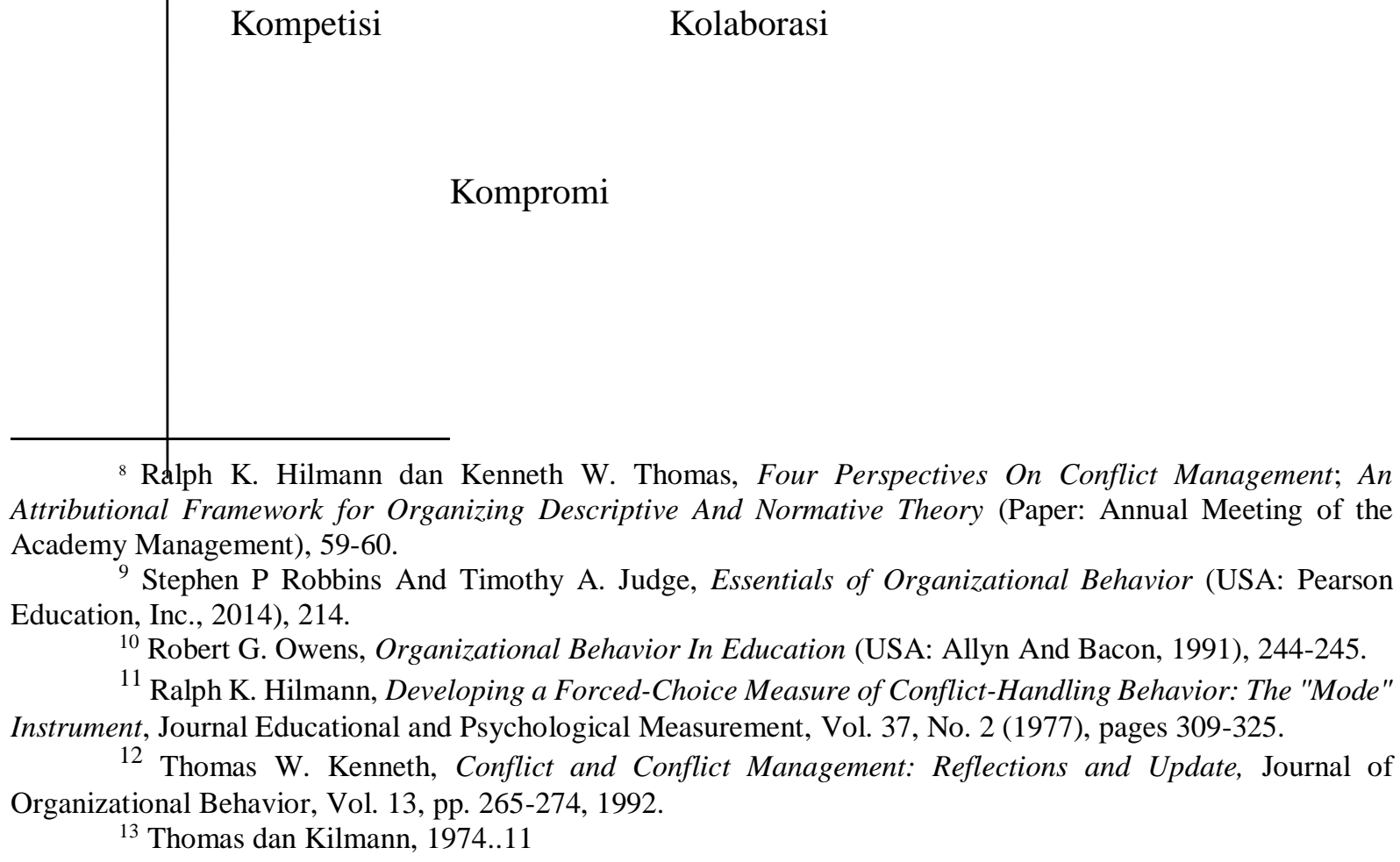

${ }^{8}$ Ralph K. Hilmann dan Kenneth W. Thomas, Four Perspectives On Conflict Management; An Attributional Framework for Organizing Descriptive And Normative Theory (Paper: Annual Meeting of the Academy Management), 59-60.

${ }^{9}$ Stephen P Robbins And Timothy A. Judge, Essentials of Organizational Behavior (USA: Pearson Education, Inc., 2014), 214.

${ }^{10}$ Robert G. Owens, Organizational Behavior In Education (USA: Allyn And Bacon, 1991), 244-245.

${ }^{11}$ Ralph K. Hilmann, Developing a Forced-Choice Measure of Conflict-Handling Behavior: The "Mode" Instrument, Journal Educational and Psychological Measurement, Vol. 37, No. 2 (1977), pages 309-325.

12 Thomas W. Kenneth, Conflict and Conflict Management: Reflections and Update, Journal of Organizational Behavior, Vol. 13, pp. 265-274, 1992.

${ }^{13}$ Thomas dan Kilmann, 1974..11 


\section{Non asertiveness}

\begin{tabular}{ll} 
Menghindar & Kompetisi \\
\hline Non Kerjasama & Kerjasama
\end{tabular}

Berdasarkan di atas dapat dikemukakan bahwa gaya manajemen konflik berporos pada dua unsur utama konflik yaitu assertiveness dan kerjasama. Pada unsur keasertifan, pihak yang berkonflik lebih memerhatikan kepentingan pribadi, sedangkan unsur kerjasama lebih memerhatikan terhadap kepentingan dan keinginan lawan konflik. Dalam pada itu, gaya manajemen konflik adalah upaya-upaya resolusi konflik dengan kecederungan pihak yang berkonflik akan kepentingan diri dan kelompoknya atau memerhatikan dengan seksama terhadap pihak lainnya.

Pada awalnya terjadi kompetisi antara pihak yang berkonflik dimana perhatian terhadap kepentingan masing-masing pihak konflik berada pada posisi yang tinggi. Masing-masing pihak memerhatikan kepentingannya sehingga eskalasi konflik semakin tinggi dan kerja sama sulit tercapai. Kompetisi konflik menunjukkan adanya kontestasi pihak-pihak yang berkonflik dengan berbagai upaya-upaya yang dilakukan untuk memenangkan kelompoknya dan menjatuhkan lawan demi mencapai kekuasaan.

Kecenderungan yang kedua adalah menghindar. Pada gaya menghindar, pihak-pihak yang berkonflik memiliki perhatian yang rendah terhadap kepentingan dirinya dengan lebih memerhatikan kepentingan lawannya. Pilihan terhadap gaya menghindar diakibatkan oleh pandangan akan kuatnya pihak lawan dan menganggap kelompoknya berada pada posisi yang lemah. Dalam perkembangannya gaya manajemen konflik berkembang dan menawarkan gaya resolusi konflik yang berpadu dengan manajemen konflik sebagai berikut.

Pengelolaan konflik pesantren merupakan upaya-upaya penanganan pergesekan mental dan emosi dalam situasi kelompok yang menjadi peningkatan atau penurunan dalam mencapai 
tujuan pesantren dalam hubungannya dengan masyarakat di Bali. ${ }^{14}$ Dalam konteks pesantren, pengelolaan konflik merupakan upaya kiai atau warga pesantren terhadap proses manajemen yang dilaksanakan secara aktif maupun pasif dengan wujud materi maupun non materi untuk mengelola pertentangan menjadi potensi dalam mencapai visi-misi pesantren. ${ }^{15}$ Jadi, pengelolaan konflik pesantren adalah kemampuan mengelola hambatan, gangguan, ancaman dan tantangan menjadi kekuatan yang dapat mengantarkan pesantren mencapai tujuannya, yaitu kehidupan masyarakat yang toleran.

Historisitas kepemimpinan Rasulullah SAW. menggambarkan adanya penyelesaian konflik secara damai. Dalam Piagam Madinah, Nabi menyusun kesepakatan yang saling menguntungkan antara Muslim dengan kaum Yahudi di Madinah. Beliau menoleransi berbagai perbedaan pemeluk dua agama tersebut. Dalam perjanjian tersebut, Muslim dengan Yahudi memiliki status yang sama di hadapan hukum. Pada saat perjanian tersebut disusun, kondisi umat Islam berada pada posisi yang kuat dibandingkan dengan Yahudi, namun tidak membuat Nabi berperilaku semena-mena. ${ }^{16}$

Sebagaimana termuat dalam Piagam Madinah pasal 16 dan 46 disebutkan bahwa kaum Yahudi yang mengikuti kami akan memeroleh hak perlindungan dan hak persamaan tanpa ada penganiayaan dan tidak ada orang yang membantu musuh mereka (pasal 16). Selanjutnya pada pasal 46 dinyatakan bahwa Yahudi al-Auz, sekutu mereka dan diri (jiwa)mereka memeroleh hak seperti apa yang terdapat bagi pemilik sahifat iniserta memeroleh perlakuan yang baik dari pemilik sahifat ini. ${ }^{17}$

\footnotetext{
14 Timothy T. Baldwin, William H. Bommer and Robert S. Rubins, Managing Organizational Behavior (New York, McGraw-Hill Irwin, 2013),378-379.

${ }^{15}$ Stephen P Robbins, Conflict Management (USA: Pearson, 1996), 201.

${ }^{16}$ Martin Lings, Muhammad; Kisah Hidup Nabi Berdasarkan Sumber Klasik (Jakarta: Serambi, 2007), 191-192.

${ }^{17}$ J. Sayuthi Pulungan, Prinsip-Prinsip Pemerintahan dalam Piagam Madinah ditinjau dari Al-Qur'an (Jakarta: Raja Grafindo Persada, 1996), 150.
} 
Pada peristiwa yang lainnya, Rasulullah SAW. pernah mengahadapi pemboikotan dan blokade ekonomi pascawafatnya Abu Thalib dan Siti Khadijah yang dikenal dengan tahun kesedihan. Kondisi tersebut berdampak pada dakwah islamiyah. Pada saat itu pemuka-pemuka Arab Jahiliyah menemui Abu Thalib menawarkan kompromi dan hidup berdampingan dengan syarat Rasulullah SAW. menghentikan aktifitas dakwah. Tawaran tersebut ditolak karena menyangkut hal-hal yang sangat prinsip, yaitu akidah (ke-Esa-an Allah). ${ }^{18}$ Dengan demikian, Islam memiliki hsitoris dalam menyelesaikan akar konflik dengan menggunakan pendekatan kepemimpinan Rasulullah SAW.

\section{METODE PENELITIAN}

Penelitian menggunakan metode kualitatif ${ }^{19}$ untuk melihat makna dari suatu tindakan atau apa yang berada di balik tindakan seseorang ${ }^{20}$ yang bersumber pada data utama penelitian, yaitu kata-kata dan tindakan. ${ }^{21}$ Dengan demikian, penggunaan metode kualitatif dapat mengantarkan peneliti memahami suatu makna di balik fenomena yang terjadi. Peneliti akan mencermati data-data tentang konflik horizontal Muslim dan Non Muslim di Bali dan bagaimana peran kiai dalam mengelola konflik. Pesantren Istiqlal Buleleng dan Bali Insani Tabanan merupakan situs penelitian.

\section{PEMBAHASAN}

\footnotetext{
${ }^{18}$ M. Quraish Shihab, Membaca Sirah Nabi Muhammad SAW dalam Sorotan al-Qur'an dan hadits-hadits Shahih (Tangerang: Lentera Hati, 2012), 421-422.

19 Penelitian kualitatif (qualitative research) adalah suatu penelitian yang ditujukan untuk mendeskripsikan dan menganilisis fenomena, peristiwa, aktifitas sosial, sikap kepercayaan, persepsi, pemikiran orang secara individual maupun kelompok. Beberapa deskripsi digunakan untuk menemukan prinsip-prinsisp dan penjelasan yang mengarah pada kesimpulan. Penelitian kualitatif bersifat induktif : atau dibiarkan terbuka untuk interpretasi. Data dihimpun dengan pengamatan yang seksama, mencakup deskripsi dalam konteks mentetail, disertai wawancara yang mendalam, serta hasil analisis dokumen dan catatan-catatan, keterangan ini diperoleh dari pemaparan Yatim Riyanto, Metode Penelitian Pendidikan (Surabaya : SIC, 2001), 24.

${ }^{20}$ Malcolm Water, "Modern Sociological Theory" dalam Nur Syam, "Tradisi Islam Lokal Pesisiran (Studi Konstruksi Sosial Upacara Pada masyarakat Pesisir Palang Tuban Jawa Timur” (Disertasi, Universitas Airlangga, Surabaya, 2003), 54.

${ }^{21}$ Moelong Lexi, Metode Penelitian Kualitatif (Bandung ; Remaja Rosdakarya, 1991), 112
} 
Sehubungan dengan konflik di Bali, Abdurrahman mengatakan:

“...hingga saat ini masih kerap terjadi cek-cok antar warga Muslim dan Hindu yang bisa terjadi akibat persoalan sepele saja". ${ }^{22}$

Pada tahun 1993 juga terjadi peristiwa pelemparan batu terhadap Masjid Mujahidin Buleleng oleh warga Hindu. ${ }^{23}$ Mereka merasa terganggu dengan bunyi pengeras suara di Masjid yang dianggap terlalu keras saat membaca puji-pujian salawat (ungkapan rasa cinta pada Nabi Muhammad) yang dibaca setiap selesai adzan dan sebelum iqamah. Tindakan tersebut dibalas oleh warga Muslim dengan membawa clurit untuk menjaga keamanan masjid dari gangguan yang lebih besar.

Pada tahun 2002 terjadi bom Bali I. Insiden berdarah tersebut menelan puluhan korban yang terdiri dari turis dan warga domestik. ${ }^{24}$ Peristiwa tersebut dituding dilakukan oleh oknum umat Islam, yang belakangan diketahui dilakukan oleh Amrozi Cs. Kejadian tersebut mengundang keprihatinan dunia terkait dengan konflik atas nama agama. Bom bali I dilanjutkan dengan Bom Bali II yang terjadi pada 01 Oktober 2005. Setelah itu terjadi bom Bali III pada tahun $2016^{25}$ yang mempertajam konflik Muslim-non Muslim.

Hubungan pesantren dan masyarakat sedikit terganggu dengan terjadinya Bom Bali tahun 2002. Tragedi tersebut menimbulkan kecurigaan masyarakat Bali terhadap kiai dan komunitas pesantren. Dua pesantren tersebut bergelut dengan masyarakat Bali dalam mengkampanyekan Islam damai. Kiai berkomunikasi secara intens, memberikan pemahaman tentang Islam yang damai dengan membangun kehidupan harmonis. Komunikasi yang

\footnotetext{
${ }^{22}$ Wawancara Abdurrahman, Konflik di Bali

${ }^{23}$ Wawancara dengan Mujahidin salah seorang tokoh Muslim di Buleleng.

24 Jawa Pos, Bom Bali 2002. Bom bali terjadi pada 12/10/2002.

${ }^{25}$ Bali Pos, Bom Bali II dan III. Edisi, 21 Oktober 2010.
} 
dilakukan kiai menghasilkan adanya pola hubungan yang saling mendukung antara pesantren dan masyarakat Bali.

Gangguan terhadap warga Muslim di Bali berlanjut. Pada tahun 2005-2006 terjadi bernuansa SARA. Pondok Pesantren di daerah Penyabangan, Sumber Kimah, Pemuteran dan Pejarakan Kecamatan Grokgak Buleleng dilarang menggunakan pengeras suara. Pelarangan disampaikan melalui surat resmi oleh pemangku adat setempat. ${ }^{26}$ Warga pesantren merespon peristiwa tersebut dengan mendatangi pihak kepolisian dan meminta mereka menyelesaikan kasus tersebut secara adil.

Insiden-insiden tersebut mengancam kehidupan harmoni kehidupan antar umat beragama, khususnya hubungan pesantren dan masyarakat Hindu-Budha di Bali. Pesantren Istiqlal dan Sunan Ampel merupakan yang terkena dampak langsung dari mirisnya pandangan masyarakat lokal maupun internasional terhadap pesantren. ${ }^{27}$ Masyarakat Muslim di Bali merasakan adanya perlakuan yang berbeda dalam hal pendanaan pengembangan pesantren yang dirasa sangat minim, jauh dari kebutuhan pendidikan dan pembinaan.

Pandangan masyarakat tersebut dibenarkan oleh, Syamsul yang menjelaskan:

“...kami harus berjuang keras dalam memeroleh dana pengembangan pondok. Jika dibandingkan dengan pembangunan dan pembinaan pura-pura jumlahnya sangat jomplang", 28

Dalam pada itu, insiden-indiden di Bali yang melibatkan komunitas Muslim dan Hindu mengundang respon negatif masyarakat terhadap pesantren. Asumsi peneliti tersebut dibenarkan oleh Ustadz Yuli ${ }^{29}$, sebagaimana dinyatakannya:

${ }^{26}$ Wawancara dengan Hadari salah seorang tokoh Muslim di Grokgak Bali.

27 Wawancara dengan Ustadz Wayan Hayaudin tanggal 05 Desember 2017. Udin adalah salah seorang staf pengajar dan pembina di Pesantren Sunan Ampel.

${ }^{28}$ Wawancara dengan Syamsul, salah seorang perangkat desa (BPD) yang merupakan pemeluk Islam taat. Dia adalah alumni pesantren di Jawa yangtelah lama terlibat dalam penyebaran Islam di Bali.

${ }^{29}$ Wawancara dengan Ustadz Yuli, salah seorang pengelola Pesantren Bali Bina Insani 20 Oktober 2017. 
“...setelah bom Bali I sumbangan masyarakat ke Pesantren kami menurun tajam. Beberapa teman yang mencari dana di beberapa Kabupaten sekitar mendapat sambutan yang kurang jika dibandingkan dengan sebelum teradinya peristiwa tersebut".

Berdasarkan pernyataan tersebut tampak adanya konflik sebagai akibat dari adanya peristiwa 'berdarah’ yang dilakukan atas nama agama.

Selain Bom Bali I, II dan III terdapat beberapa peristiwa konflik antara umat Muslim dengan Hindu. Misalnya Konflik Pengastulan pada tahun 2010. Dari peristiwa tersebut warga Muslim sempat terisolasi selama tiga hari. ${ }^{30}$ Pada tahun yang sama konflik antar warga beda agama kembali meledak sehingga mengakibatkan pulhan rumah rusak. ${ }^{31}$ Bahkan pada saat perayaan Nyepi, dua kelompok warga terlibat bentrok. Peristiwa tersebut dipicu oleh kesalahpahaman antara kedua belah pihak.

Pada tahun 2017, terjadi keributan akibat oknum yang merebut mikropon pengeras suara yang digunakan untuk mengumandangkan azan subuh. Seseorang yang sedang kalap merampas mikropon tersebut dan berusaha menghentikan pelaksanaan azan. Peristiwa tersebut dilaporkan kepada Mapolda Bali dan dapat diselesaikan secara damai. ${ }^{32}$ Beberapa pihak yang dikonfirmasi peneliti mengaku tidak tahu dengan kejadian tersebut. Beberapa diantaranya berusaha menghindari pertanyaan peneliti.

Pada tahun yang sama (2017) di daerah Gitgit terjadi longsor yang menimpa satu unit mushalla sehingga mengalami kerusakan berat. Akibat kejadian tersebut umat Muslim tidak dapat shalat secara berjamaah sebagaimana telah rutin dilaksanakan. Pihak pemerintahan desa setempat menolak melakukan renovasi untuk memperbaiki mushalla tersebut. Diketahui bahwa mushalla dimaksud telah dibangun sejak tahun 1950-an. ${ }^{33}$

${ }^{30}$ Majalah Hidayatullah, Sempat Terisolir 3 hari warga Muslim Pengastulan Sudah Mulai Beraktifitas, Edisi, 31/08/2010, 50.

${ }^{31}$ Bali Pos, Konflik antar Warga Kembali Pecah, Edisi 30/08/2010

${ }^{32}$ Wawancara dengan Arifi, Kepala KUA Denpasar, 01 Maret 2018.

${ }^{33}$ Wawancara dengan Harisuddin, 30 Januari 2018. 
Di Singaraja terdapat satu Masjid yang semakin meningkat jumlah jamaahnya sehingga saat ini tidak memuat pelaksanaan salat secara berjamaah. Pengelola masjid berupaya melakukan pengembangan pembangunan masjid dengan maksud membeli sebidang tanah yang terselak berdampingan dengan tempat ibadah tersebut. Namun demikian hingga saat ini pemilik tanah enggan menjual tanah kepada manajemen masjid tanpa alasan yang jelas. Panitia pengembangan masjid berniat membelinya dengan harga jual tanah yang cukup tinggi. ${ }^{34}$

Upaya pengembangan pesantren di Bali diwarnai oleh gesekan. Pada tahun 1992 terjadi bentrok antara masyarakat Hindu dengan warga Muslim di Kampung Kauman, Slirit Buleleng Bali. ${ }^{35}$ Bentrok tersebut dipicu oleh adanya kesalah-pahaman yang meluas menjadi konflik horizontal antara warga dalam jumlah yang cukup besar. Konflik tersebut bisa diselesaikan dengan adanya kesepakatan damai antara kedua pihak untuk saling menghormati keberagaman.

Bentrok kembali terjadi tahun 1993. Insiden tersebut melibatkan unsur Muslim dan Hindu yang dipicu oleh persoalan pemuda yang mabuk-mabukan lalu mendapat respon dari masyarakat Muslim. Menurut Abdurrahman, konflik di Bali terjadi hampir tiap tahun, namun tidak terekspos secara luas mengingat kejadiannya yang bernuansa SARA (suku, agama, ras dan adat.

Secara konflik, hubungan pesantren dan masyarakat mengalami dilema. Mereka merupakan dua entitas yang saling memengaruhi dan mendukung. Hubungan masyarakat dengan pesantren bersifat dialektis, problematik dan saling mengisi. Pesantren didirikan dari, oleh, untuk masyarakat. Pesantren yang ada ditengah-tengah masyarakat memang memiliki ciri khas yang berbeda dengan masyarakatnya namun tidak terpisah. Pesantren ada untuk

\footnotetext{
${ }^{34}$ Wawancara dengan Ahmadi, pengurus PCNU Singaraja, 14 Februari 2018.

${ }^{35}$ Wawancara dengan Abdrrahman, Konflik di Bali, 22 Januari 2018. Dia adalah Ketua Yayasan Masjid Mujahidin Sumber Kimah dan salah seorang yang terlibat dalam konflik Slirit.
} 
memenuhi kebutuhan masyarakat dan masyarakat ada untuk berkonstribusi terhadap pesantren. Namun demikian, konflik telah meretakkan hubungan keduanya menjadi renggang.

Konflik pesantren lahir dari hubungan dialektis masyarakat dengan pesantren yang mewujud pada, tingkat dan dampak konflik terhadap pesantren. Wujud konflik berupa fisik, nilai dan pendanaan. Adapun tingkat konflik bisa tinggi, rendah maupun sedang yang merepresentasikan kepasifan dan keaktifan. Karakteristik, peran dan konstribus kepemimpinan harus relevan dengan tantangan yang dihadapi berupa konflik pesantren yang berdampak terhadap delapan inti manajemen pendidikan Islam.

Beberapa peristiwa di atas memunculkan pandangan sumir terhadap pesantren. Beberapa kalangan memandang pesantren sebagai sarang teroris. ${ }^{36}$ Mereka memiliki pemahaman yang kurang tepat terhadap pesantren yang dianggap anti toleran dan anti globalisasi. Selain itu, terdapat beberapa pesantren non mainstream yang terkesan tertutup dan tidak beradaptasi dengan budaya lokal. Mereka disebut memiliki pemahaman Islam yang kaku dan memandang sesuatu yang berbdea dengan mereka sebagai bid' $a h^{37}$ bahkan kafir.

Namun dibalik itu, kerajaan-kerajaan di Bali secara cerdik menggunakan jasa orang Islam, tidak saja sebagai penggerak roda perdagangan, tetapi juga untuk memupuk modal sosial guna dialihkan bagi kepentingan tenaga militer maupun panjak dilingkungan puri dan gerilya. ${ }^{38}$ Pemukiman mereka dikarantinaisasikan sehingga terbentuk koesistensi secara damai, karena yang satu tidak mengganggu yang lainnya dalam mengembangkan identitasnya agama (Hindu, xii.

${ }^{36}$ Syamsul Ma’arif, Pesantren Inklusif Berbasis Kearifan Lokal (Yogyakarta: Kaukaba Dipantara, 2015),

${ }^{37}$ Bid'ah adalah perilaku yang tidak dipraktikkan pada masa Nabi dan para Sahabat. Aliran-aliran dalam Islam memiliki persepsiyang berbeda dalam memahami praktik bid'ah. Ada yang lentur dan ada yang ketat. NU termasuk organisasi Islam di indonesia yang memiliki sikap berimbang dalam memahami kearifan lokal sehingga cenderung akomodatif.

${ }^{38}$ Nengah Bawa Atmaja, Geneologi Keruntuhan Majapahit Islamisasi, Toleransi dan Pemertahanan Agama Hindu di Bali (Yogyakarta: Pustaka Pelajar, 2010), 425. 
Islam) maupun etnik. Kesemuanya tidak bisa pula dilepaskan dari toleransi yang dirancang oleh elite politik dan agama atas dukungan orang Islam yang bermukim di Bali. ${ }^{39}$

Bali merupakan satu-satunya propinsi yang masih tetap bisa mempertahankan agama Hindu sebagai basis bagi kebudayaan. Pada awalnya, Bali adalah bagian tidak terpisahkan dari Majapahit. Ketika kerajaan terbesar di Nusantara tersebut runtuh, masyarakat Majapahit pindah ke Bali. Dalam perkembangannya, Bali dikenal sebagai pewaris dan pelanjut tradisi Majapahit. $^{40}$

Selanjutnya, Bali berkembang menjadi pusat kebudayaan Hindu-Budha terbesar di Nusantara. Keindahan alam di Bali menarik para wisatawan domistik maupun luar negeri menikmati panorama alam dan budayanya. Para pelancong tersebut membawa kebiasaan, perilaku dan budayanya masing-masing bercampur dengan budaya Bali yang khas. Budaya Bali bergeser akibat adanya globalisasi dan transformasi budaya.

Kondisi tersebut merupakan tantangan besar bagi kiai-kiai pesantren di Bali. Sejak awal berdirinya pesantren di Bali, kiai menempuh pendekatan budaya organisasi. Pendekatan kebudayaan menjadi pilihan strategis kiai. Dalam pandangan masyarakat Bali kiai identik dengan tokoh keagamaan kharismatik sebanding dengan, ulama, ustadz, buya, ajengan di Jawa Barat dan Syekh di Minangkabau. ${ }^{41}$ Sosok kiai dihormati oleh masyarakatnya karena merupakan pemimpin pesantren yang membaktikan hidupnya untuk membangun masyarakat berperadaban melalui praktik dan peran keagamaaan. Dalam kerangka itulah, kiai mencerminkan muslim terpelajar. ${ }^{42}$

\footnotetext{
${ }^{39}$ Atmaja, Geneologi.., 450.

${ }^{40}$ Hasbullah, Dasar-dasar Pendidikan, (Jakarta: Raja Grafindo Persada, 1999), 138.

${ }^{41}$ Abdurahman Wahid, Menggereakkan Tradisi, (Yogyakarta: LKiS, 2001), 171-172. Lihat juga IAIN Syarif Hidayatullah, Ensiklopedi Islam Indonesia (Jakarta: Penerbit Djambatan, 1992), 562.

${ }^{42}$ Hasanatul Jannah, Kiai, Perubahan Sosial dan Politik Kekuasaan, Fikrah, No 3, 2015, 159.
} 
Di sisi lain, faktor konflik juga muncul dari internal umat Islam. Hal ini didasarkan pada pendapat Mastuhu yang mengatakan bahwa sistem pendidikan di Indonesia mengandung aspek-aspek diskriminasi dan terlepas dari jiwa masyarakat yang dalam praktiknya terkesan eksklusif dan elitis. ${ }^{43}$ Dari pernyataan Mastuhu tampak bahwa lembaga pendidikan memberikan sumbangsih terhadap situasi konflik yang terjadi di masyarakat. Asumsi tersebut perlu ditelaah secara mendalam karena fungsi pendidikan adalah memanusiakan manusia dalam melakukan perannya sebagai pelaku perubahan mayarakat.

Pendapat senada juga disampaikan oleh Bastian yang menyatakan bahwa sistem pendidikan di Indonesia berorienasi pada pengetahuan verbalistik dan melupakan aspek nilai dalam penerapannya. ${ }^{44}$ Kecenderungan tersebut memunculkan adanya sikap primordial yang hanya menganggap diri dan kelompoknya lebih baik dan lebih benar atas yang lain. ${ }^{45}$ Sikap primordial tersebut mengakibatkan adanya tindakan yang merugikan pihak lain dengan mengatas-namakan kebenaran suatu agama, ras, adat dan suku tertentu.

Menyikapi fenomena konflik pesantren dan masyarakatnya, kiai melakukan berbagai strategi berupa resolusi konflik yang dilakukan dengan masyarakat Bali dilakukan melalui memahami kultur dan perilaku masyarakatnya. Simbol-simbol komunikasi kiai adalah menyelipkan nama-nama khas Bali dalm sebutan ke-kiai-annya. Misalnya pengasuh pesantren Istiqlal Kiai Ketut Amar Ma’ruf, Kiai Wayan Syahiruddin (Pengasuh Pesantren Sunan Ampel), Kiai Ketut Imaduddin Djamal, I Wayan Syamsul Bahri yang sekarang menjadi Kepala Kemenag Jawa Timur. Pilihan nama-nama marga Bali tersebut merupakan simbol komunikasi verbal yang dilakukan kiai dalam rangka perpaduan budaya Islam dan Bali.

\footnotetext{
${ }^{43}$ Mastuhu, Menata Ulang Pemikiran Sistem Pendidikan Nasional dalam Abad 21 (Yogyakarta: Safiria Insari Press, 2003), 33.

${ }^{44}$ A. Reza Bastian, Reformasi Pendidikan (Yogyakarta: Lappera Pustaka Utama, 2002), 35.

${ }^{45}$ Hidayat, Komaruddin at.all. 2001. Agama di engah Kemelut. (Jakarta: Mediacita, 2001), 280-281.
} 
Internalisasi nilai dan penyatuan dilakuakan dengan mengaitkan nama-nama pesantren di Bali juga dekat dengan budaya masyarakat. Istiqlal dan Bina Bali adalah nama yang disenangi oleh masyarakat Bali sebagai penyebar agama Islam yang toleran. Uniknya, 16 guru yang beragama Budha dan Hindu mengajar di Pesantren. Mereka memberika ilmunya secara suka rela tanpa memandang perbedaan latar belakang agama, suku maupun budaya. Fenomena tersebut menunjukkan keberhasilan pesantren menarik simpati masyarakat di sekitarnya.

Fenomena Pesantren Bali Bina Insani menggambarkan kemampuan kiai dalam berkomunikasi dengan masyarakat Bali menjadikan pesantren diterima, besar dan kuat. Melalui strategi budaya organisasi semacam itulah, lambat laun, eksistensi kiai dan pesantren diakui oleh masyarakat Bali sebagai panutan. Kiai juga memberikan bantuan dan membaur dengan masyarakat sekitar pesantren.

"Saya menghormat Hari Raya umat lain di Bali. Misalnya tidak membunyikan pengeras suara saat hari nyepi. Bahkan juga tidak memakai lampu". ${ }^{46}$

Kiai menyadari bahwa pendidikan adalah tanggungjawab bersama antara pemerintah, pesantren dan masyarakat. Tanpa dukungan masyarakat, pendidikan tidak akan berhasil dengan maksimal. ${ }^{47}$ Pandangan kiai di atas menunjukkan adanya simpati dan perhatian yang besar akan adanya kebersamaan dalam mengembangkan pesantren. Pemahaman tersebut mengindikasikan bahwa konflik-konflik yang terjadi di Bali di luar kemauan agama. Bagaimanapun, agama tidak mengajarkan kekerasan dalam bentuk apapun.

Pesantren Istiqlal dan Bali Bina Insani dikelola dengan melibatkan guru-guru Hindu. Dari penelusuran peneliti didapatkan data, 16 guru Hindu mengajar di Bali Bina Insani. ${ }^{48}$ Dan

\footnotetext{
${ }^{46}$ Wawancara dengan Wayan Syahiruddin.

47 St. Rodliyah, Partisipasi Masyarakat dalam Pengambilan Keputusan dan Perencanaan di Sekolah (Jember: STAIN Jember Press, 2012), 15.

${ }^{48}$ Wawancara dengan Ustadz Yuli
} 
17 guru Hindu mengajar di Istiqlal $^{49}$. Berdasarkan data tersebut menunjukkan adanya manajemen kiai terhadap umat non Muslim dalam menyampaikan pengetahuan terhadap peserta didik. Kiai menyadari bahwa tugas memberikan pengetahuan tidk terbatas oleh sekatsekat agama, suku, adat dan ras. Kesadaran tersebut telah menghadirkan adanya kepedulian dari pihak luar pesantren untuk bekerja sama, bahu membahu mengembangkan pendidikan pesantren.

Kiai memiliki perilaku yang unik dan problematik. Dia dipandang sebagai pranata kebudayaan yang memiliki unsur genealogis dengan masyarakat dan pesantren. ${ }^{50}$ Eksistensi kiai mengindikasikan seseorang yang taat menjalankan ajaran agamanya secara komprehensif dan holistik. Peran dan karakteristik kiai mewujud dalam kelembagaan pesantren. Perilaku kiai terejawantah dalam peran dan karakteristik yang mencerminkan fungsi-fungsi yang kompleks, sebagai ahli hukum, pengajar, aktor perubahan sosial dan pelayan bagi masyarakatnya.

\section{KESIMPULAN}

Atas dasar kajian sebagaimana dianalisis pada bagian diskusi, penulis menyampaikan kesimpulan sebagai berikut:

Pertama, varian konflik di Bali adalah horizontal dengan melibatkan komunitas Muslim dan Non Muslim yang terjadi akibat adanya disharmoni dan kesalahpahaman. Konflik-konflik di Bali berbentuk interpersonal dan berkembang menjadi antar komunitas Muslim Non Muslim hingga meluas pada skala nasional bahkan global mengingat lokus Bali sebagai pusat destinasi pariwisata internasional. Terdapat satu hal yang penting dan mendasar dimana konflik selalu terjadi akibat adaya miskomunikasi antar pihak yang berkonflik, sehingga sudah seeharusnya dibangun adanya saling pemahaman yang mendalam melalui adanya komunikasi yang intens didasari dengan local wisdom dan komitmen terhadap ajaran agamanya masing-masing.

\footnotetext{
${ }^{49}$ Wawancara dengan Kiai Amar

${ }^{50}$ Aswab Mahasin, Kemanunggalan Kiai, Santri dan Pesantren (Jakarta: Bumi Aksara, 1990), 51.
} 
Kedua, kiai menerapkan pola penyelesaiakan konflik yang bertumpu pada gaya kompromi karena memiliki pemahaman dan keyakinan yang tinggi terhadap kebenaran ajaran agama Islam. Kiai memiliki sikap inklusif sehingga mau dan mampu menerima perbedaan sebagai historis dan mengelola konflik menjadi kekuatan dalam mengembangkan pendidikan pesantren toleran karena meneladani pandangan dan perilaku profetik. Strategi pendidikan pesantren toleran di Bali dapat menjadi panduan bagi dunia dalam mengelola dan menyelesaikan konflik kemanusiaan yang salalu merugikan kehidupan umat manusia.

\section{DAFTAR PUSTAKA}

Atmaja, Nengah Bawa. 2010. Geneologi Keruntuhan Majapahit Islamisasi, Toleransi dan Pemertahanan Agama Hindu di Bali. Yogyakarta: Pustaka Pelajar.

Baldwin, Timothy T., Bommer, William H. and Rubins, Robert S. 2013. Managing Organizational Behavior. New York, McGraw-Hill Irwin.

Bashori. 2017. "Manajemen Konflik Di Tengah Dinamika Pondok Pesantren Dan Madrasah" Muslim Heritage, Vol.1 nomor 2 November 2016-April.

Bastian A. Reza. 2002. Reformasi Pendidikan. Yogyakarta: Lappera Pustaka Utama.

Chaudhry, Atif Masood And Asif, Rehman. 2015. "Organizational Conflict and Conflict Management; A Synthesis Of Literature". Journal of Business and Management Research, 9.

Ghorbani, Mahmood And Razavi, Nazanin Homaye. 2011. the study of reletionship between organizational culture and conflict management. Middle East Journal Of Scientific Research 10 (2).

Hasbullah. 1999. Dasar-dasar Pendidikan. Jakarta: Raja Grafindo Persada.

Hidayat, Komaruddin at.all. 2001. Agama di engah Kemelut. Jakarta: Mediacita.

Hilmann, Ralph K. 1977. "Four Perspectives On Conflict Management; An Attributional Framework for Organizing Descriptive And Normative Theory”. Paper: Annual Meeting of the Academy Management.

Hilmann, Ralph K. 1977. Developing a Forced-Choice Measure of Conflict-Handling Behavior: The "Mode" Instrument. Journal Educational and Psychological Measurement. Vol. 37, No. 2.

Jannah, Hasanatul. 2015. Kyai, Perubahan Sosial, dan Dinamika Politik Kekuasaan: Jurnal Ilmu Aqidah dan Studi Keagamaan Vol. 3, No. 1, Juni.

Kenneth, Thomas W. 1992. Conflict and Conflict Management: Reflections and Update, Journal of Organizational Behavior, Vol. 13.

Lexi, Moelong. 1991. Metode Penelitian Kualitatif. Bandung ; Remaja Rosdakarya.

Lings, Martin. Muhammad; Kisah Hidup Nabi Berdasarkan Sumber Klasik. Jakarta: Serambi. 
Ma'arif, Syamsul. 2015. Pesantren Inklusif Berbasis Kearifan Lokal. Yogyakarta: Kaukaba Dipantara.

Mastuhu. 2003. Menata Ulang Pemikiran Sistem Pendidikan Nasional dalam Abad 21. Yogyakarta: Safiria Insari Press.

Owens, Robert G. 1991. Organizational Behavior In Education. USA: Allyn And Bacon.

Pulungan, J. Sayuthi. 1996. Prinsip-Prinsip Pemerintahan dalam Piagam Madinah ditinjau dari Al-Qur'an. Jakarta: Raja Grafindo Persada.

Riyanto, Yatim. 2001. Metode Penelitian Pendidikan. Surabaya : SIC.

Robbins, Stephen P And Judge. 2014. Timothy A. Essentials of Organizational Behavior. USA: Pearson Education, Inc.

Rodliyah, St. 2012. Partisipasi Masyarakat dalam Pengambilan Keputusan dan Perencanaan di Sekolah. Jember: STAIN Jember Press

Wahid, Abdurahman. 2001. Menggereakkan Tradisi. Yogyakarta: LKiS.

Water, Malcolm. 2003. "Modern Sociological Theory” dalam Nur Syam, "Tradisi Islam Lokal Pesisiran (Studi Konstruksi Sosial Upacara Pada masyarakat Pesisir Palang Tuban Jawa Timur”. Disertasi, Universitas Airlangga, Surabaya. 